\title{
THE EFFECTIVENESS OF GEOGEBRA-BASED VAN HIELE MODEL ON MATHEMATICAL DISPOSITION ASSESSED FROM EARLY MATHEMATICS ABILITY
}

\author{
Widyah Noviana $^{1}$, Windia Hadi ${ }^{2}$, Ita Handayani ${ }^{3}$ \\ ${ }^{1}$ Universitas Pamulang, Jl. Surya Kencana No.1 Pamulang, Tangerang Selatan, Indonesia \\ dosen02314@unpam.ac.id \\ ${ }^{2}$ Universitas Muhammadiyah Prof. DR. HAMKA, Jalan Tanah Merdeka, DKI Jakarta, Indonesia. \\ windia.hadi@uhamka.ac.id \\ ${ }^{3}$ Universitas Pamulang, Jl. Surya Kencana No.1 Pamulang, Tangerang Selatan, Indonesia \\ dosen01947@unpam.ac.id
}

\begin{abstract}
The aim of this research was to observe the effectiveness of geogebra based van hiele model on mathematical disposition assessed from early mathematics ability. The accessible population of the present study was students of Prof. DR. HAMKA Muhammadiyah University. Samples of this research is semester two students from mathematics education program. Due to the happening Covid-19 pandemic, the present study was conducted online. The method employed was quasi-experiment using factorial treatment by level $2 \times 2$ design. The data were collected with mathematical disposition questionnaire and early mathematics ability instrument. After the data were collected, they were then analyzed with two-way ANAVA analysis. The result showed that there was no significant difference in the increase mathematical disposition of students who are given the learning model and early mathematics ability. The conclusion obtained is that the geogebra based Van Hiele Model is ineffective on students' mathematical disposition in terms of their early mathematics abilitiy. This is due to several factors, namely internal factors and external factors. The internal factors are decreas in the score of mathematical disposition from pretest to posttest, lack of understanding applying geogebra software with online learning. External factors are quotas and poor internet network.
\end{abstract}

\section{ARTICLE INFORMATION}

\begin{tabular}{l}
\hline Keywords \\
\hline Van Hiele model \\
GeoGebra \\
Mathematical disposition \\
Early mathematics ability \\
\hline
\end{tabular}

Article History

Submitted Aug 31, 2020

Revised Nov 22, 2020

Accepted Nov 22, 2020

\section{Corresponding Author}

Widyah Noviana

Universitas Pamulang

Jl. Surya Kencana No.1 Pamulang, Tangerang Selatan, Indonesia

Email: dosen02314@unpam.ac.id

\section{How to Cite}

Noviana, W., Hadi, W., \& Handayani, I. (2020). The Effectiveness of Geogebra-Based Van Hiele Model on Mathematical Disposition Assessed from Early Mathematics Ability. Kalamatika: Jurnal Pendidikan Matematika, 5(2), 167-180.

https://doi.org/10.22236/KALAMATIKA.vol5no2.2020pp167-180 


\section{INTRODUCTION}

We are currently in the beginning of the fourth industrial revolution or simply industry 4.0, in which cyber and digital industry have become a reference for people's lifestyle, especially in education. As science and technology keep developing, mathematics education should also adapt itself to this industry 4.0. Teaching methods from previous era should also be updated and followed by mathematics teachers, that is by making use of ICT and software in the learning process. One of mathematics subjects in college that could use software in learning process is geometry.

Learning geometry is helpful in daily life. As for example, a student is required to make an equilateral triangle, that student has to first understand the concepts of geometry principles in order to avoid mistakes when making the triangle. The student could use a postulate that drawing equilateral triangle could be started from drawing a circle. (S)he could use a compass in the process of making the triangle. An understanding of geometry is required in determining a shape. Most students consider geometry to be a difiicult subject because of its abstract concepts. This makes students less confidents in solving geometry problems. This results in students seeing that mathematics is difficult to understand and students' interest in learning mathematics is reduced (Nurfitriyanti, 2017). This is in line with research by Nopriana (2015) which states that problems that are not understood by students allow students not to have a strong determination to solve math problems. Lack of confidence in learning mathematics, lack of interest in solving math problems ahows that the mathematical position of students is still low. Based on the results of the TIMSS report in 2011 regarding the attitudes of Indonesian students at level 8 towards mathematics compared to Malaysia and Singapore, it can be seen in table 1.

Table 1. Percentage of Students' Attitudes Toward Mathematics in TIMSS 2011

\begin{tabular}{lccc}
\hline Country & $\begin{array}{c}\text { Like Learning } \\
\text { Mathematics }\end{array}$ & $\begin{array}{c}\text { Somewhat Like Learning } \\
\text { Mathematics }\end{array}$ & $\begin{array}{c}\text { Do not Like Learning } \\
\text { Mathematics }\end{array}$ \\
\hline Malaysia & $39 \%$ & $46 \%$ & $15 \%$ \\
Singapore & $32 \%$ & $44 \%$ & $23 \%$ \\
Indonesia & $20 \%$ & $70 \%$ & $10 \%$ \\
International Average & $26 \%$ & $42 \%$ & $31 \%$ \\
\hline
\end{tabular}

Based on the 2011 TIMSS report on students attitudes towards mathematics, it can be seen that the attitude of Indonesian students who like learning mathematics as much as $20 \%$ has an average below the international average while the attitude of disliking learning mathematics has better results among developing countries. Namely $10 \%$ and as many as $70 \%$ of Indonesian 
students who rather like learning mathematics. From the facts above, it shows that the attitude of students in liking mathematics is still low. The low attitude of students in liking to learning mathematics can be the basis for fostering a positive attitude towards mathematics. Positif attitudes that can be developed such as interest, interest, perseverance, confidence and confidence to explore solving mathematical problems. The development of an interest in mathematics will form a strong tendency (Widyasari, Dahlan, \& Dewanto, 2016).

The low positive attitude towards mathematics is the low students' disposition. This is in line with (I. Handayani, 2018), disposition is a belief accompanied by positive actions towards mathematics. The low mathematical disposition of students is possible because it does not relate material to uses in everday life, so learning seems boring. This is in accordance with (R. Rahayu, Kartono, \& Sulhadi, 2014). Mathematical disposition is defined as the tendency to see mathematics as something that can be understood, something that makes sense and is usefull believing that effort, perseverance in learning mathematics will provide good results and act as an effective student.

One of the students' affective in learning mathematics is known as mathematical disposition (Jatiariska, Sariyasa, \& Astawa, 2020). According to Kemendikbud (2016) the affective domain determines a person's learning success. This is in line with Kusmaryono, Suyitno, Dwijanto, \& Dwidayati, 2019; Lin \& ChunTai (2016) teacher need to focus not just on the development of math knowledge and skills, but on the development of the mathematics disposition and also should optimize the dispositional mental functions of the students by selecting a learning model, affective and conative. Mathematical disposition is, therefore, strong willingness, awareness, dedication, and tendency of a student to think and act mathematically in a positive manner (Akbar, Hamid, Bernard, \& Sugandi, 2017). National Council of Teachers of Mathematics stated that mathematics disposition includes the ability to take a risk and explore solutions to various problems, dedication to solve challenging problems, take responsibility to make a job done, respect the power of communication of mathematics language, willingness to ask questions and propose mathematical ideas, have high self-esteem, and treat a problem as a challenge (NCTM, 2000). This all could be seen when a student is in a learning process and solve mathematics problem. Thus, mathematical disposition are abilities that are very important for students, because they can affect many things to learning mathematics and daily life. 
One of learning models that is considered appropriate to encourage students' mathematical disposition is Van Hiele model. This is line of research (eg. Noriza \& Kartono, 2009) says van hiele geometric approach is effective to mathematical diposition. Van Hiele model is a theory proposed by Van Hiele that focuses on learning stages and level thinking of geometry. The learning stages in the Van Hiele model are information, directed oriented, explication, free orientation, and integration (Al-ebous, 2016; Alex \& Mammen, 2018; Pujawan, Suryawan, \& Prabawati, 2020). In the information stage, students ask questions to stop initial skills before learning Euclidean geometry. At the directed orientation stage, students make observations to understand a concept. At the affirmation stage, students can explain both verbally and as a form of communication of their ideas. In the free orientation stage, it allows students to solve more complicated Euclidean geometry problems. The last stage, namely integration, allows students to reflect on the geometric thinking process.Van Hiele's theory is a theory about the level of thinking of students in studying geometry, one of which is a flat shape, where students cannot go up to a higher level without passing the lower level (Musa, 2018). The most prominent learning begins with the "van hiele model" by Dina Van Hiele Geldof and Piere Marie Van Hiele. Van Hiele's theory plays a very important role in the rules of understanding geometry, interpretation and determining the level of development of geometric thinking.The levels are visualisation, analysis, informal deduction, formal deduction, and rigor (Abdullah \& Zakaria, 2013). The first level is visualisation level. At this level, students are able to introducing and naming geometric shape. The second level students are able to identify the properties of certain shapes. The third level students have done sorting or deduction informal. The fourth level students thingking stage has developed, student can appreciate the meaning postulates, theorems, and proofs. Finally, the fifth level in Van Hiele's model is rigor. Students come to thingking complex geometry and understand how to work in an axiomatic system.

To transform high level of spatial imagination to be a real visualization, a software is required. GeoGebra is a mathematical software that combines geometry, algebra, and calculus in which this software could help provide clear information in a form of an image and understanding mathematics concept, therefore GeoGebra is beneficial for both students and lecturers (Siswanto, 2015; Zulnaidi \& Zamri, 2017). Attitudes and habits of good thinking will form and develop a good mathematical disposition, in addition to the learning model, student early mathematical ability also affect students' mathematical dispositions. The habituation of 
the directed Van Hiele Model Learning stage can provide a positive experience and a good impression for students so that learning geometry becomes closer.

According to Akinsola \& Odeyemi (2014), early mathematics ability affects students in interpreting new information and decide whether or not the information is relevant. The development of students' knowledge uses their early mathematics ability to connect already understood concepts to understand a new one. Early ability is considered important prerequisite to learn new concept and could form individual knowledge and result of the learning process (F. Handayani \& Lestari, 2019; Noviana, Suyono, \& Hakim, 2018; Widodo, 2016). Early ability possessed by the students could also provide assessment whether all information and concepts understood are related to new concepts or topics being learned. Given that fact, the students would be motivated to learn topics that are being learned. (I. Handayani, 2018) seconds this with her statement that stated students who have early ability about the concept that is related to new topic would feel enthusiastic in learning the topic, it is due to the fact that they already understand the concepts related to the topic discussed.

Based on previous research, it emphasizes the level of geometric thinking seen from van hiele theory and the use of props in the learning process, following other studies (eg. Fitriyani, Widodo, \& Hendroanto, 2018; Koswara, W., \& Rosita, 2017). From the above researchers to develop mathematical dispositions seen from the van hiele model by adding geogebra software based on early mathematical abilities. Based on what has been described above, the purpose of this study is to determine the effectiveness of the geogebra based van hiele model on mathematical dispositions in terms of students' early mathematics ability.

\section{METHOD}

The method employed was quasi-experiment using factorial treatment by level $2 \times 2$ design and research design is non equivalent pre-test and post-test control group design (Ruseffendi, 2010) The present study design is illustrated as follows:

$$
\begin{array}{cc}
\text { E: O X O } \\
\text { C: O O }
\end{array}
$$

Notes:

E : Experiment Class

$\mathrm{K} \quad$ : Control Class

X : Euclidean geometry learning using Geogebra-Based Van Hiele Model 
O : Pretest and posttest mathematical disposition given for experiment class and control class

------- : Sample are not grouped randomly

Population in the present study was all population target at faculties of teacher training and education at universities in East Jakarta. The accessible population of the present study was all students at Muhammadiyah Prof. DR. HAMKA University. The research sampling technique was obtained through purposive sampling and random sampling techniques. Purposive sampling is used when determining the mathematics education study program students as the sample. Random sampling is used when determining class. Classes were selected by random sampling so that 4 classes, namely class $2 \mathrm{~B}$ and $2 \mathrm{C}$ were treated using the geogebra based van hiele model (as an experimental class) and class $2 \mathrm{~A}$ and $2 \mathrm{E}$ were given conventional learning treatment (as a control class). The independent variable in this study is the Van Hiele Model Based on Geogebra and conventional learning, the dependent variable is mathematical disposition and the control variable is the students early mathematics ability which is divided into two categories, namely high early mathematical ability and low early mathematical ability.

The collecting data in this study used a mathematical disposition questionnaire and an instrument of early mathematics ability test. The early mathematics ability tes was carried out before being given treatment. Early mathematics ability were obtained from the results of the Euclid Geometry mid semester student exam even semester 2019-2020. Furthermore, from each experimental class and control class, a total of $33 \frac{1}{3} \%\left(M_{T}=M_{R}=33 \frac{1}{3} \%\right)$ where the numbers were quite contrast and reliable (Naga, 2009) As many as $33 \frac{1}{3} \%$ of the students with the highest score were the sample with high early mathematical ability and $33 \frac{1}{3} \%$ of the students with the lowest score became the sample of the study with low early mathematical ability. Furthermore, at the begunning of the study students were given a mathematical disposition pretest and athe the end of the study, students were given the same questionnaire, namely the mathematical disposition questionnaire.

Technique of analyzing students mathematical disposition data in term of students; early abilities begins with the prerequisite test, namely the normality and homogeneity test. Then the research hypothesis test used two way ANAVA with help of SPSS 21. Two way ANAVA was used to test the differences in mathematical dispositions between students treated with the 
Geogebra-based Van Hiele Model and coneventional learning. If there is a difference, the proceed with the t-test to test the difference in the average value of mathematical dispositions based on the sample group.

\section{RESULT AND DISCUSSION}

Student pretest data were obtained before getting treatment. This data is used to determine the initial state of students before getting treatment. The following is the data pretest result for the experimental and control classes.

Table 2. The Pretest Data for Experiment and Control Class

\begin{tabular}{|c|c|c|c|c|c|c|c|c|c|}
\hline \multirow[t]{2}{*}{ Aspects measure } & \multirow[t]{2}{*}{ Score } & \multirow[t]{2}{*}{$\begin{array}{l}\text { Early } \\
\text { Mathematics } \\
\text { Ability }\end{array}$} & \multirow[t]{2}{*}{$\mathrm{N}$} & \multicolumn{3}{|c|}{$\begin{array}{c}\text { Geogebra-Based Van Hiele } \\
\text { Model } \\
\text { (Experiment) }\end{array}$} & \multicolumn{3}{|c|}{$\begin{array}{l}\text { Conventional } \\
\text { (Control) }\end{array}$} \\
\hline & & & & Min. & Maks. & $\bar{x}$ & Min. & Maks. & $\bar{x}$ \\
\hline \multirow{2}{*}{$\begin{array}{l}\text { Mathematical } \\
\text { Disposition }\end{array}$} & \multirow[t]{2}{*}{ Pretest } & High & 15 & 73 & 91 & 84,80 & 75 & 96 & 83,47 \\
\hline & & Low & 15 & 72 & 96 & 82,67 & 67 & 94 & 81,53 \\
\hline
\end{tabular}

Based on Table 2, the average pretest mathematical disposition results for the Geogebrabased Van Hiele Model class at higher early mathematics ability and lower early mathematics ability are higher than conventional learning classes. Furthermore, the data normality test was carried out. The normality test aims to determine the distribution of the selected sample from a normal or abnormal population (Kadir, 2010). The result of the normality test using liliefors for the initial test scores in the experimental and control classes are shown in table 3.

Tabel 3. Normality Pretest Data for Experiment and Control Class

\begin{tabular}{lcccc}
\hline \multirow{2}{*}{ Class } & \multicolumn{3}{c}{ Uji Shapiro-Wilk } & \multirow{2}{*}{ Information } \\
\cline { 2 - 4 } & Stat. & Df. & Sig. & \\
\hline Geogebra-Based Van Hiele Model(Experiment) & 0,984 & 30 & 0,926 & $\mathrm{H}_{0}$ accepted \\
Conventional (Control) & 0,969 & 30 & 0,503 & $\mathrm{H}_{0}$ accepted \\
\hline
\end{tabular}

Based on table 3, it can be seen that the significance value for the Shapiro-Wilk test of students who were treated with the Geogebra-based Van Hiele Model and students who were given conventional treatment were 0.926 and 0.503 , respectively, more than 0.05 , so that $\mathrm{H}_{0}$ was accepted. So, it can be concluded that the two-pre-test data are mathematically distributed normally. Because the two samples come from normally distributed data, a homogeneity test will be carried out to find out whether the two samples come from populations with the same variance or not (Riadi, 2015). The homogeneity test was carried out using the Levene Statistic test. 
Table 4. Homogeneity Test of Pretest Data for Experiment and Control Class

\begin{tabular}{lcccc}
\hline LeveneStatistic & $d f_{1}$ & $d f_{2}$ & Sig. & Keterangan \\
\hline 1,330 & 3 & 56 & 0,274 & $\mathrm{H}_{0}$ accepted \\
\hline
\end{tabular}

Based on Tabel 4, it can be seen that the significance value for levene's test of students who were terated with the geogebra-based Van Hiele Model and the Conventional class was 0,274 . This significance value is more than 0,05 , so that $\mathrm{H}_{0}$ is accepted. This shows that the variance of the pretest data of students treated with the Geogebra-based Van Hiele Model and Conventional class is homogeneous. After receiving treatment, a final test is carried out for testing the hypothesis. The following is the post test data for the experimental and control classes.

Table 5. The Post Test Data for Experiment and Control Class

\begin{tabular}{lccccccccc}
\hline $\begin{array}{l}\text { Aspects } \\
\text { measure }\end{array}$ & Score & $\begin{array}{c}\text { Early } \\
\text { Mathematics } \\
\text { Ability }\end{array}$ & $\mathrm{N}$ & \multicolumn{2}{c}{$\begin{array}{c}\text { Geogebra-Based Van Hiele } \\
\text { Model } \\
\text { (Experiment) }\end{array}$} & \multicolumn{3}{c}{$\begin{array}{c}\text { Conventional } \\
\text { (Control) }\end{array}$} \\
\cline { 3 - 11 } & & & & Min. & Maks. & $\bar{x}$ & Min. & Maks. & $\bar{x}$ \\
\hline Mathematical & Post test & High & 15 & 69 & 100 & 83,13 & 75 & 96 & 84,27 \\
Disposition & & Low & 15 & 72 & 95 & 84,73 & 68 & 93 & 81,07 \\
\hline
\end{tabular}

Based on Tabel 5, the average results of the mathematical disposition of students treated with the Geogebra-Based Van Hiele Model at high early mathematical ability are lower than students who are given conventional learning treatment at high early mathematics ability. But the average results of the mathematical disposition of students treated with the Geogebra-based Van Hiele Model at low early mathematics ability were higher than students who were treated with conventional learning. Furthermore, the data normality test was carried out. Following are the results of the normality test of the experimental class data.

Table 6. Normality Post Test Data for Experiment and Control Class

\begin{tabular}{|c|c|c|c|c|}
\hline \multirow{2}{*}{ Class } & \multicolumn{3}{|c|}{ Uji Shapiro-Wilk } & \multirow{2}{*}{ Information } \\
\hline & Stat. & $D f$. & Sig. & \\
\hline Geogebra-Based Van Hiele Model(Experiment) & 0,967 & 30 & 0,471 & $\mathrm{H}_{0}$ accepted \\
\hline Conventional (Control) & 0,965 & 30 & 0,416 & $\mathrm{H}_{0}$ accepted \\
\hline
\end{tabular}

Based on table 6, it can be seen that the significance value for the Shapiro-Wilk test of students who were treated with the Geogebra-based Van Hiele Model and students who were given conventional treatment were $0.926>0,05$ and $0.503>0.05$, so that $\mathrm{H}_{0}$ was accepted. So, it can be concluded that the two pre-tests data are mathematically distributed normally. Because the two samples come from normally distributed data, a homogeneity test will be carried out to find out whether the two samples come from populations with the same variance or not. The 
homogeneity test was carried out using the Levene Statistic test.

Table 7. Homogeneity Test of Post Test Data for Experiment and Control Class

\begin{tabular}{lcccc}
\hline LeveneStatistic & $d f_{1}$ & $d f_{2}$ & Sig. & Information \\
\hline 3,317 & 1 & 58 & 0,074 & $\mathrm{H}_{0}$ accepted \\
\hline
\end{tabular}

Based on Table 7, it can be seen that the significance value for levene's test of students who were terated with the geogebra-based Van Hiele Model and the Conventional class was 0,074. This significance value is more than 0,05 , so that $\mathrm{H}_{0}$ is accepted. This shows that the variance of the pretest data of students treated with the Geogebra-based Van Hiele Model and Conventional class is homogeneous. After the prerequisite test was fulfilled, the two way ANAVA test was the carried out using SPSS version 21. So based on the SPSS results, the results of the model, early mathematics ability and the interaction between the model and early mathematical ability were obtained. Below are the result Two way Anava of the GeogebraBased Van Hiele Model to mathematical disposition.

Table 8. The Result Two Way Anava

\begin{tabular}{lccc}
\hline \multicolumn{1}{c}{ Source } & F & Sig. & Ho \\
\hline Model & 0.442 & 0.509 & Accepted \\
Early Mathematics Ability & 0.176 & 0.676 & Accepted \\
Model*Early Mathematics Ability & 1.587 & 0.213 & Accepted \\
\hline
\end{tabular}

Based on table 8 , it shows that the significance value of the model is $0,509>0,05$, this shows that there is no significant difference in the the increase in the mathematical disposition of students who are given the Geogebra-based Van Hiele Model treatment and conventional learning. Furthermore, we obtained the significance value of $0,676>0,05$, this shows that there is no significant difference in the increase in mathematical disposition between students who have high and low early mathematical ability categories. Based on table 8 , it is also found that the significance value for the interaction between Model and early mathematics ability is 0,213 $>0,05$, this indicates that there is no significant interaction effect between the learning model and early mathematical ability on the score of mathematical disposition. Because there is no difference in the increase in the mathematical disposition of students who are treated with the Van Hiele Model Based on Geogebra and students who are given conventional learning treatment, further testing of each category group cannot be done. This also shows that the Geogebra-based Van Hiele Model is not effective in improving students' mathematical dispositions. The results of this study are supported by research (eg. Almerino, Jr., Etcuban, De 
Jose, \& Almerino, 2019; Nopriana, 2015) which states that there is no significant difference between the van hiele model with mathematical disposition and mathematical disposition with gender, further more Dina, Ikhsan, \& Hajidin (2019) states that there is no the interaction between mathematical dispositions and learning models.

In the results of data analysis during the learning during the learning process, it is known that the results of the mathematical disposition questionnaire that were treated with the Geogebra-based Van Hiele Model obtained $47 \%$ or as many as 14 students experienced a decrease in scores from pretest to posttest from a total of 30 students treated with the Geogebrabased Van Hiele Model. From the observation in direct experiment through online learning due to Covid-19 pandemic, it is found that many obstacles faced by the students in experiment proses in GeoGebra-based Van Hiele model application were found, namely limited data plan, unstable connection, and the lack of students understanding to operate the GeoGebra software when learning online. In addition, understanding pictures in GeoGebra software is very necessary, meanwhile Perbowo, Hadi, \& Haryati (2017) research shows that there are $16.67 \%$ of students on low level having a difficulty on representing figures/mathematical object into mathematical model; $70 \%$ of students on medium level having a trouble on understanding the information given in the problem and the way they express it into symbols, and $13.33 \%$ of students on high level do not provide clarity within every step taken in their answer. This caused the students feel bored when studying which results in their mathematics disposition drop. This is supported by (Widyasari et al., 2016) who stated that mathematics disposition highly depends on intrinsic and extrinsic factors in each individual. Therefore, strong willingness of a student is required to fulfill all disposition indicators. In addition, GeoGebra-based Van Hiele model in online learning encourages students to develop their thinking skills by solving problems, however, many obstacles faced by the students make them less confident in communicating their ideas, and the students tend to not have strong willingness in solving geometry problems if they do not understand how to solve it (Nopriana, 2015).

\section{CONCLUSION}

The result showed that there was no significant difference in the increase mathematical disposition of students who are given the learning model and early mathematics ability. The conclusion obtained is that the geogebra based Van Hiele Model is ineffective on students' mathematical disposition in terms of their early mathematics abilitiy. From the results of the 
research and discussion, it was concluded that there was no interaction between the learning model and early mathematics ability on mathematical dispositions. This is due to several factors, namely internal and external factors. Internal factors are a decrease in the score of mathematical disposition from pretest to posttest, lack of understanding of students in applying geogebra software with online learning and student and student boring in online learning. External factors are quota and bad internet network

\section{ACKNOWLEDGMENTS}

The researcher says to thank the Directorate of Research and Community Service, Directorate General of Research and Development Strengthening Ministry of Research, Technology and Higher Education following Research Contract Number: 0180/D5/KP/AMD/LPPM/UNPAM/VI/2020and also to students who participated and assisted the data collection process in this study.

\section{REFERENCES}

Abdullah, A. H., \& Zakaria, E. (2013). Enhancing students' level of geometric thinking through van hiele's phase-based learning. Indian Journal of Science and Technology, 6(5), 44324446.

Akbar, P., Hamid, A., Bernard, M., \& Sugandi, A. I. (2017). Analisis Kemampuan Pemecahan Masalah Dan Disposisi Matematik Siswa Kelas Xi Sma Putra Juang Dalam Materi Peluang. Jurnal Cendekia: Jurnal Pendidikan Matematika, 2(1), 144-153. https://doi.org/10.31004/cendekia.v2i1.62

Akinsola, M. K., \& Odeyemi, E. O. (2014). Effects of Direct and Indirect Instructional Strategies on Students ${ }^{\text {ee }}$ Achievement in Mathematics. International Journal of Education and Research, 2(7), 675-688. https://doi.org/10.4314/afrrev.v6i4.24

Al-ebous, T. (2016). Effect of the Van Hiele Model in Geometric Concepts Acquisition: The Attitudes towards Geometry and Learning Transfer Effect of the First Three Grades Students in Jordan. International Education Studies, 9(4), 87. https://doi.org/10.5539/ies.v9n4p87

Alex, J., \& Mammen, K. J. (2018). Students' understanding of geometry terminology through 
the lens of Van Hiele theory. Pythagoras, 39(1), 1-8. https://doi.org/10.4102/pythagoras.v39i1.376

Almerino, Jr., P. M., Etcuban, J. O., De Jose, C. G., \& Almerino, J. G. F. (2019). Students' Affective Belief as the Component in Mathematical Disposition. International Electronic Journal of Mathematics Education, 14(3), 475-487. https://doi.org/10.29333/iejme/5750

Dina, Z. H., Ikhsan, M., \& Hajidin, H. (2019). The Improvement of Communication and Mathematical Disposition Abilities through Discovery Learning Model in Junior High School. JRAMathEdu (Journal of Research and Advances in Mathematics Education), 4(1), 11-22. https://doi.org/10.23917/jramathedu.v4i1.6824

Fitriyani, H., Widodo, S. A., \& Hendroanto, A. (2018). Students' Geometric Thinking Based on Van Hiele'S Theory. Infinity Journal, $7(1), \quad$ https://doi.org/10.22460/infinity.v7i1.p55-60

Handayani, F., \& Lestari, W. (2019). Journal of Educational Research and Evaluation Need Analysis in The Development of HOTS-Oriented Study Project Assesment Instrument in Android-Based Science Learning. Jere, 8(1), 57-64.

Handayani, I. (2018). Pengaruh Model Pembelajaran CORE dalam Meningkatkan Disposisi Matematis ditinjau dari Kemampuan Awal Matematika Peserta Didik SMP Negeri di Jakarta Selatan. In KNPMP III (pp. 123-132).

Jatiariska, I. G. A., Sariyasa, \& Astawa, I. W. P. (2020). The Influence of Knisley Mathematical Learning Model with Geogebra Towards Mathematical Connection and Mathematical Disposition. Journal of Physics: Conference Series, 1503(1), 0-8. https://doi.org/10.1088/1742-6596/1503/1/012013

Kadir. (2010). Statistika. Jakarta: PT. Rosemata Sampurna.

Kemendikbud. (2016). Permendikbud No. 21 tentang Standar Isi untuk Satuan Pendidikan Dasar dan Menengah. Jakarta: Kemendikbud. 
Koswara, U., W., T. Y., \& Rosita, N. T. (2017). Pelatihan Program Geogebra Bagi Guru Matematika Smp Di Kabupaten Sumedang. E-Dimas, 8(1), 77. https://doi.org/10.26877/e-dimas.v8i1.1376

Kusmaryono, I., Suyitno, H., Dwijanto, D., \& Dwidayati, N. (2019). The effect of mathematical disposition on mathematical power formation: Review of dispositional mental functions. International Journal of Instruction, 12(1), 343-356. https://doi.org/10.29333/iji.2019.12123a

Lin, S.-W., \& ChunTai, W. (2016). A Longitudinal Study for Types and Changes of Students' Mathematical Disposition. Universal Journal of Educational Research, 4(8), 19031911. https://doi.org/10.13189/ujer.2016.040821

Musa, L. A. D. (2018). Level Berpikir Geometri Menurut Teori Van Hiele Berdasarkan Kemampuan Geometri dan Perbedaan Gender Siswa Kelas VII SMPN 8 Pare-Pare. AlKhwarizmi: Jurnal Pendidikan Matematika Dan Ilmu Pengetahuan Alam, 4(2), 103116. https://doi.org/10.24256/jpmipa.v4i2.255

Naga, D. . (2009). Teori Skor Pada Pengukuran Mental. Jakarta: PT. Nagarani Citrayasa.

NCTM. (2000). Standards for School Mathematics. Reston, Va: NCTM.

Nopriana, T. (2015). FIBONACCI Jurnal Pendidikan Matematika \& Matematika. FIBONACCI Jurnal Pendidikan Matematika \& Matematika, 1(2), 80-94.

Noriza, M. D., \& Kartono. (2009). Kemampuan Pemecahan Masalah dan Disposisi Matematis Berdasarkan Tingkat Berpikir Geometri pada Model PBL, 19(19), 347-355.

Noviana, W., Suyono, \& Hakim, L. EL. (2018). Pengaruh Pendekatan M-APOS Terhadap Kemampuan Penalaran Matematis Siswa SMP Negeri di Kota Tangerang. Jurnal Riset Pendidikan Matematika Jakarta, 1, 31-38.

Nurfitriyanti, M. (2017). Peningkatan Kemampuan Disposisi Matematika Melalui Pembelajaran Berbasis Aktivitas Siswa. Jurnal Susunan Artikel Pendidikan, 2(1), 84-93. 
Perbowo, K. S., Hadi, W., \& Haryati, T. (2017). Profile of mathematical communication skillviewed with problem-solving skill: a case of secondary students, 65-69.

Pujawan, I. G. N., Suryawan, I. P. P., \& Prabawati, D. A. A. (2020). The effect of van hiele learning model on students' spatial abilities. International Journal of Instruction, 13(3), 461-474. https://doi.org/10.29333/iji.2020.13332a

R. Rahayu, Kartono, \& Sulhadi. (2014). The Effect Of Mathematical Disposition On Pmri Toward Problem Solving Abililt Based On Ideal Problem Solver. International Journal of Science and Research (IJSR), 3(10), 1315-1318.

Ruseffendi, E. . (2010). Statistika Dasar Untuk Penelitian Pendidikan. Bandung: IKIP Bandung Press.

Siswanto, R. D. (2015). Penerapan Pembelajaran Inkuiri Terbimbing berbantuan GeoGebra untuk Meningkatkan Kemampuan Geometri Spasial, Berpikir Kreatif Matematis dan Kemandirian Belajar Siswa SMP. Universitas Pendidikan Indonesia.

Widodo, S. A. (2016). Efektivitas Pembelajaran Team Accelerated Instruction Terhadap Kemampuan Memecahkan Masalah Matematika Siswa Kelas Viii Smp Kota Jogjakarta. AdMathEdu : Jurnal Ilmiah Pendidikan Matematika, Ilmu Matematika Dan Matematika Terapan, 5(2). https://doi.org/10.12928/admathedu.v5i2.4774

Widyasari, N., Dahlan, J. A., \& Dewanto, S. (2016). Meningkatkan Kemampuan Disposisi Matematis Siswa Smp Melalui Pendekatan Metaphorical Thinking. FIBONACCI: Jurnal Pendidikan Matematika Dan Matematika, 2(2), 28. https://doi.org/10.24853/fbc.2.2.28-39

Zulnaidi, H., \& Zamri, S. N. A. S. (2017). The effectiveness of the geogebra software: The intermediary role of procedural knowledge on students' conceptual knowledge and their achievement in mathematics. Eurasia Journal of Mathematics, Science and Technology Education, 13(6), 2155-2180. https://doi.org/10.12973/eurasia.2017.01219a 